\title{
Modulation of Substance P Signaling by Dipeptidyl Peptidase-IV Enzymatic Activity in Human Glioma Cell Lines
}

\author{
P. BUŠEK, J. STREMEŇOVÁ, E. KŘEPELA, A. ŠEDO
}

Joint Laboratory of Cancer Cell Biology of the First Faculty of Medicine, Charles University in Prague, and the Institute of Physiology, Academy of Sciences, Prague, Czech Republic

Received February 28, 2007

Accepted April 30, 2007

On-line October 11, 2007

\section{Summary}

Dipeptidyl peptidase-IV (DPP-IV, CD26) is a serine protease almost ubiquitously expressed on cell surface and present in body fluids. DPP-IV has been suggested to proteolytically modify a number of biologically active peptides including substance $P$ (SP) and the chemokine stromal cell derived factor-1 $\alpha$ (SDF- $1 \alpha$, CXCL12). SP and SDF-1 $\alpha$ have been implicated in the regulation of multiple biological processes and also induce responses that may be relevant for glioma progression. Both SP and SDF-1 $\alpha$ are signaling through cell surface receptors and use intracellular calcium as a second messenger. The effect of DPP-IV on intracellular calcium mobilization mediated by SP and SDF- $1 \alpha$ was monitored in suspension of wild type U373 and DPP-IV transfected U373DPPIV glioma cells using indicator FURA-2. Nanomolar concentrations of SP triggered a transient dose dependent increase in intracellular calcium rendering the cells refractory to repeated stimulation, while SDF- $1 \alpha$ had no measurable effect. SP signaling in DPP-IV overexpressing U373DPPIV cells was not substantially different from that in wild type cells. However, preincubation of SP with the DPP-IV overexpressing cells lead to the loss of its signaling potential, which could be prevented with DPP-IV inhibitors. Taken together, DPP-IV may proteolytically inactivate local mediators involved in gliomagenesis.

\section{Key words}

Dipeptidyl peptidase • Substance P • Glioma • NK1 receptor • Calcium signaling

\section{Corresponding author}

Aleksi Šedo, Institute of Biochemistry and Experimental Oncology, $1^{\text {st }}$ Faculty of Medicine, Charles University, U Nemocnice 5, 12853 Prague 2, Czech Republic, Fax: +420 224 965 826. E-mail: aleksi@cesnet.cz

\section{Introduction}

Dipeptidyl peptidase-IV (DPP-IV, CD26) is a widely expressed $240 \mathrm{kDa}$ serine protease with a multitude of functions under both physiological and pathological conditions (for review see Lambeir et al. 2003). Its relatively restricted substrate specifity for proline or alanine in the $\mathrm{P} 1$ position directs its action on a number of biologically active peptides such as neuropeptide Y, substance $\mathrm{P}$ (SP), glucagon-like peptide-1 and -2 and a number of chemokines including stromal cell-derived factor-1 $\alpha$ (SDF-1 $\alpha$, CXCL12) (Mentlein 1999, de Meester et al. 2000). Proteolytic removal of the two N-terminal amino acid residues by DPP-IV mostly decreases the biological activity of the corresponding peptide, while in some cases it can activate the peptide substrate or influence its binding to specific receptor subtypes (Mentlein 1999). DPP-IV is mostly expressed on cell surface and a soluble form is also present in the serum (Durinx et al. 2000). DPP-IV enzymatic activity can therefore affect auto-, para- as well as endocrine signaling of biologically active substances.

DPP-IV is frequently dysregulated in cancer, being significantly down-regulated or lost in some tumors and upregulated in others (Sulda et al. 2006). A number of DPP-IV substrates promote the malignant phenotype of cancer cells that express appropriate receptors. Thus, DPP-IV hydrolytic activity can interfere with some prooncogenic signaling pathways (Bušek et al. 2004, 2006). Indeed, Masur et al. (2006) have recently shown that a DPP-IV inhibitor can promote the growth stimulating and migratory effect of glucagon-like peptide-2 in DPP-IV

PHYSIOLOGICAL RESEARCH • ISSN 0862-8408 (print) • ISSN 1802-9973 (online)

(c) 2008 Institute of Physiology v.v.i., Academy of Sciences of the Czech Republic, Prague, Czech Republic

Fax +420 241062 164, e-mail: physres@biomed.cas.cz,www.biomed.cas.cz/physiolres 
positive colon cancer cell lines. Interestingly, in vitro studies have mostly demonstrated that artificial upregulation of DPP-IV has an antioncogenic effect (Wesley et al. 1999, 2004, 2005), although the mechanism remains elusive.

In brain tumors, DPP-IV substrates SP and SDF$1 \alpha$ trigger a number of intracellular signaling cascades that affect cell proliferation, survival, migration and invasion (Barbero et al. 2003, Palma and Maggi 2000, Sharif 1998). Indeed, antagonists of the corresponding receptors NK1 and CXCR4 exhibit significant antitumor activity in gliomas (Palma et al. 2000, Rubin et al. 2003). We have previously detected expression and activity of DPP-IV and possibly other molecules bearing similar enzymatic activity, e.g. fibroblast activation protein- $\alpha$, dipeptidyl peptidases 8 and 9 in human glioma tumors and cell lines (Šedo et al. 2004, Stremeňová et al. 2006). Here we explore, whether DPP-IV enzymatic activity can influence signaling of selected biologically active DPPIV substrates in glioma cell lines.

\section{Methods}

\section{Chemicals and cell lines}

Human SDF-1 $\alpha$ was purchased from PeproTech (UK), SP, Diprotin A and Lys[Z(NO2)]-pyrrolidide were from Bachem (Switzerland). Glioma cell lines U373 and T98G (ATCC, USA) and their transfectants (U373DPPIV, T98GDPPIV) were cultured in Dulbecco's Modified Eagle's Medium with $10 \%$ fetal bovine serum (Sigma, Czech Republic) under standard conditions. DPP-IV was transfected into U373 and T98G cells using the mifepristone inducible Gene Switch System (Invitrogen, USA). The transfectants inducibly expressed DPP-IV upon treatment with $5 \mathrm{nM}$ Mifepristone (mife). Maximum DPP-IV upregulation was achieved after 24 hours in U373DPPIV and after 48 hours in T98GDPPIV cells.

\section{Real time RT-PCR}

Total RNA was isolated using the TriZol Reagent (Invitrogen, UK) according to the manufacturer's instructions. Spectrophotometric analysis, carried out in $10 \mathrm{mmol} / \mathrm{l}$ Tris/HCl buffer, $\mathrm{pH} 7.5$, revealed that the samples of total RNA had an A260 nm/A280 nm ratio greater than 1.8. The concentration of total RNA was determined using the RiboGreen RNA Quantitation Kit (Molecular Probes, Eugene, USA).

Gene coding region-specific oligonucleotide primers and fluorogenic TaqMan probes for the real time RT-PCR assays of expression of the investigated transcripts were designed with the program Primer Express (Applied Biosystems, USA) and were synthesized at Proligo (France) and Applied Biosystems (UK), respectively (Table 1). The expression of DPP-IV, NK1 receptor, CXCR4 and $\beta$-actin mRNA (an internal reference transcript) was quantified by coupled real time RT-PCR assays. The RT-PCR reaction mixtures of a total volume of $50 \mu \mathrm{l}$ contained $25 \mu \mathrm{l}$ of ThermoScript Reaction Mix (a buffer with $3 \mathrm{mmol} / \mathrm{l} \quad \mathrm{MgSO}_{4}$ and $0.2 \mathrm{mmol} / \mathrm{l}$ of each dGTP, dCTP, dATP and dTTP) and $1 \mu \mathrm{l}$ of ThermoScript Plus Reverse Transcriptase/ Platinum Taq DNA polymerase Mix (both mixes were from Platinum Quantitative RT-PCR ThermoScript OneStep System, Invitrogen), the respective gene-specific primers and TaqMan probe, 40 units of RNase inhibitor RNaseOUT (Invitrogen), and an input of $200 \mathrm{ng}$ of total RNA. The real time RT-PCR assays were run in duplicate in MicroAmp Optical 96-well Reaction Plates on the ABI PRISM 7700 Sequence Detection System operated by the Sequence Detection System software (Applied Biosystems). The reverse transcription was carried out at $58{ }^{\circ} \mathrm{C}$ for $30 \mathrm{~min}$ and the subsequent PCR amplification included a hot start at $95{ }^{\circ} \mathrm{C}$ for 5 min and 45 cycles of denaturation at $95{ }^{\circ} \mathrm{C}$ for $15 \mathrm{~s}$ and of annealing/extension at $58^{\circ} \mathrm{C}$ for $1 \mathrm{~min}$. The threshold cycle $(\mathrm{Ct})$ values of the amplification reactions, represented by the plots of background-subtracted fluorescence intensity $(\Delta \mathrm{FI})$ of the reporter dye (6-FAM or VIC) against PCR cycle number, were determined with the Sequence Detection System software. Target transcript expression was normalized to $\beta$-actin mRNA expression using the $\Delta \mathrm{Ct}$ method and the linearized $\Delta \mathrm{Ct}$ (i.e. $2^{-\Delta \mathrm{Ct}}$ ) was used for comparative purposes (Livak and Schmittgen 2001).

\section{DPP-IV enzymatic activity assay}

Cell surface DPP-IV enzymatic activity was assessed in suspensions of viable cells by a continuous rate fluorimetric assay using 7-(glycyl-L-prolylamido)-4methylcoumarin (Gly-Pro-AMC; Bachem, Switzerland) as substrate at $\mathrm{pH} 7.5$ and $37^{\circ} \mathrm{C}$ (Šedo et al. 1989).

\section{Measurement of intracellular calcium}

Mobilization of intracellular $\mathrm{Ca}^{2+}$ was monitored in cell suspensions at $37{ }^{\circ} \mathrm{C}$ after loading cells with the ratiometric indicator FURA-2 (final concentration $4 \mu \mathrm{mol} / \mathrm{l}$ ) for $30 \mathrm{~min}$ and scraping the cells gently into a Krebs buffer $(120 \mathrm{mmol} / \mathrm{l} \mathrm{NaCl}, 4.75 \mathrm{mmol} / \mathrm{l} \mathrm{KCl}$, 
Table 1. Primers and TaqMan probes used for real time RT-PCR quantitation of expression of the investigated transcripts

\begin{tabular}{|c|c|c|}
\hline & GeneBank & \\
\hline Transcript & Accession No. & Sequences and final concentration of primers and TaqMan probes \\
\hline DPP-IV & NM_001935 & $\begin{array}{ll}\text { Forward primer: } & 5 '-\text { TGGAAGGTTCTTCTGGGACTG-3', } 200 \mathrm{nmol} / 1 \\
\text { Reverse primer: } & \text { 5'-GATAGAATGTCCAAACTCATCAAATGT-3', } 200 \mathrm{nmol} / 1 \\
\text { TaqMan probe: } & 5 '-(6 \text {-FAM) CACCGTGCCCGTGGTTCTGCT (TAMRA)-3', } 200 \mathrm{nmol} / 1\end{array}$ \\
\hline NK1 & NM_001058 & Forward primer: 5'-CAGTGGTGAACTTCACCTATGCT-3', $400 \mathrm{nmol} / 1$ \\
\hline \multicolumn{3}{|c|}{ Reverse primer: 5'-GATGTATGATGGCCATGTACCTATC-3', $400 \mathrm{nmol} / \mathrm{l}$} \\
\hline & & $5^{\prime}-(6$-FAM) TCCACAACTTCTTTCCCATCGCCG (TAMRA) - 3 ', $200 \mathrm{nmol} / 1$ \\
\hline CXCR4 & NM_001008540 & $\begin{array}{ll}\text { Forward primer: } & 5 ' \text {-CATGGGTTACCAGAAGAAACTGA-3', } 400 \mathrm{nmol} / 1 \\
\text { Reverse primer: } & 5 \text { '-GACTGCCTTGCATAGGAAGTTC-3', } 400 \mathrm{nmol} / 1 \\
\text { TaqMan probe: } & 5 '-(6 \text {-FAM) CACCTGTCAGTGGCCGACCTCCT (TAMRA)-3', } 200 \mathrm{nmol} / 1\end{array}$ \\
\hline$\beta$-Actin & NM_001101 & $\begin{array}{ll}\text { Forward primer: } & 5 '-\text {-CTGGCACCCAGCACAATG-3', } 200 \mathrm{nmol} / 1 \\
\text { Reverse primer: } & \text { 5'-GGGCCGGACTCGTCATAC-3', } 200 \mathrm{nmol} / 1 \\
\text { TaqMan probe: } & 5 \text { '-(VIC) AGCCGCCGATCCACACGGAGT (TAMRA)-3', } 200 \mathrm{nmol} / 1\end{array}$ \\
\hline
\end{tabular}

Table 2. Expression of DPP-IV and receptors of its biologically active substrates in wild type glioma cell lines (U373 and T98G) and transfected cells (U373DPPIV and T98GDPPIV) stimulated (mife + ) or not stimulated (mife -) to express DPP-IV.

\begin{tabular}{|c|c|c|c|c|}
\hline & \multirow{2}{*}{$\begin{array}{l}\text { Relative cell surface } \\
\text { DPP-IV enzymatic } \\
\text { activity } / 10^{6} \text { cells }\end{array}$} & \multicolumn{2}{|c|}{ Relative mRNA expression $\left(2^{-\mathrm{ACt}}\right) \times 10^{-3}$} & \multirow[b]{2}{*}{ CXCR4 } \\
\hline & & DPP-IV & NK1 & \\
\hline \multicolumn{5}{|l|}{ Wild cells } \\
\hline U373 & $1.0 \pm 0.1$ & $3.148 \pm 1.138$ & $1.129 \pm 0.338$ & $0.627 \pm 0.055$ \\
\hline$T 98 G$ & $0.7 \pm 0.1$ & $0.004 \pm 0.001$ & $0.011 \pm 0.003$ & $0.286 \pm 0.067$ \\
\hline \multicolumn{5}{|l|}{ Transfected cells } \\
\hline U373DPPIVmife - & $2.4 \pm 0.1$ & $89.630 \pm 17.872$ & $2.314 \pm 0.628$ & $0.195 \pm 0.067$ \\
\hline U373DPPIV mife + & $27.4 \pm 0.5$ & $663.675 \pm 63.162$ & $5.097 \pm 1.062$ & $0.665 \pm 0.095$ \\
\hline T98GDPPIV mife - & $1.3 \pm 0.1$ & $36.818 \pm 10.271$ & $0.143 \pm 0.083$ & $0.078 \pm 0.042$ \\
\hline T98GDPPIV mife + & $543.7 \pm 90.0$ & $2444.720 \pm 326.319$ & $0.005 \pm 0.001$ & $0.074 \pm 0.026$ \\
\hline
\end{tabular}

The expression of DPP-IV, NK1 receptor and CXCR4 mRNAs was normalized to the expression of human $\beta$-actin mRNA. Data are presented as means \pm SEM of at least three measurements.

$1 \mathrm{mmol} / 1 \quad \mathrm{KH}_{2} \mathrm{PO}_{4}, 5 \mathrm{mmol} / \mathrm{l} \quad \mathrm{NaHCO}_{3}, 1.44 \mathrm{mmol} / \mathrm{l}$ $\mathrm{MgSO}_{4}, 1.1 \mathrm{mmol} / 1 \mathrm{CaCl}_{2}, 0.1 \mathrm{mmol} / 1 \mathrm{EGTA}, 11 \mathrm{mmol} / \mathrm{l}$ glucose, $25 \mathrm{mmol} / \mathrm{l}$ NaHEPES, $0.1 \%$ bovine serum albumin fraction $\mathrm{V}, \mathrm{pH}$ 7.4). Fluorescence was measured at $340 \mathrm{~nm} / 380 \mathrm{~nm}$ (excitation) and $510 \mathrm{~nm}$ (emission) on a Perkin Elmer spectrofluorometer. Stock solution of SP was added to the cuvette with tested cells either directly or after 10-30 min of preincubation at $37{ }^{\circ} \mathrm{C}$ with T98GDPPIV cells induced or not induced to upregulate DPP-IV. Concentration of intracellular calcium was calculated using the equation $\left[\mathrm{Ca}^{2+}\right]_{\mathrm{i}}=\mathrm{K}_{\mathrm{d}} \mathrm{x}$ (R$\left.\mathrm{R}_{\min }\right) /\left(\mathrm{R}_{\max }-\mathrm{R}\right) \times \mathrm{SFB}$, where $\mathrm{R}$ is the emission ratio value (340 nm/380 nm). $R_{\max }$, the maximum $340 \mathrm{~nm} / 380 \mathrm{~nm}$ ratio, was determined by lysing the cells with $0.1 \%$ Triton X-100 in the presence of $1 \mathrm{mmol} / \mathrm{CaCl}_{2}$. The $\mathrm{R}_{\min }$ $340 \mathrm{~nm} / 380 \mathrm{~nm}$ ratio was obtained by adding $40 \mathrm{mmol} / \mathrm{l}$
EGTA. $\mathrm{K}_{d}$ is the dissociation constant of the Fura- $2 / \mathrm{Ca}^{2+}$ complex $(225 \mathrm{nmol} / \mathrm{l})$ and $\mathrm{SFB}$ is the ratio of $380 \mathrm{~nm}$ fluorescences under $\mathrm{Ca}^{2+}$-free/ $\mathrm{Ca}^{2+}$ saturated conditions. Trypsin, which is known to induce calcium oscillations in glioma cells (Ubl et al. 1998), was used at a final concentration of $10^{-4} \mathrm{~g} / \mathrm{l}$ as a positive control for the above described $\left[\mathrm{Ca}^{2+}\right]_{\mathrm{i}}$ rise measuring method.

\section{Results}

To quantify the potential of our model cell lines to proteolytically process biologically active DPP-IV substrates, cell surface DPP-IV enzymatic activity was determined in wild type U373 and T98G cells and in their transfected counterparts U373DPPIV and T98GDPPIV. Cell surface DPP-IV enzymatic activity was upregulated 

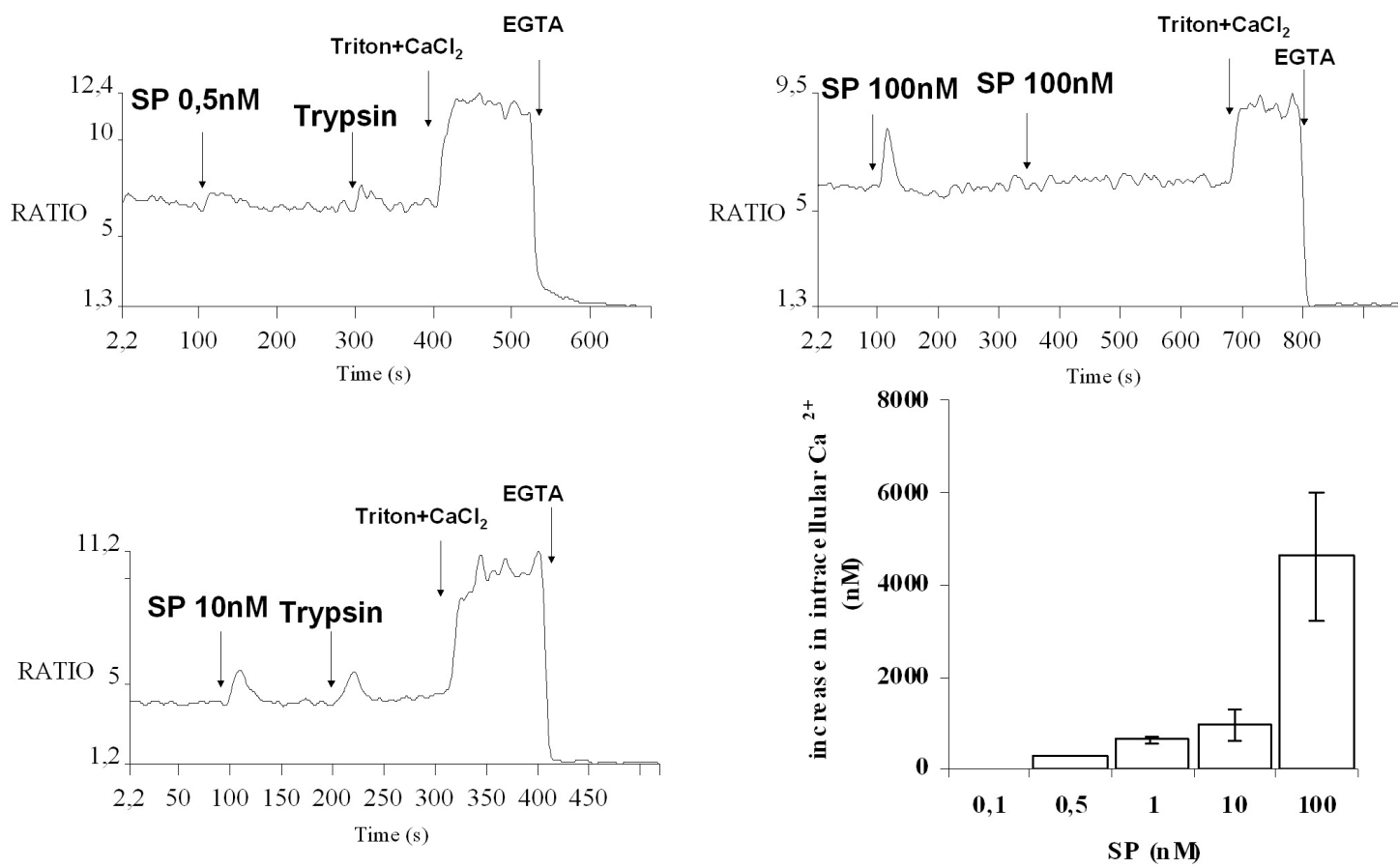

Fig. 1. Substance $P$ triggers concentration-dependent mobilization of intracellular calcium in U373 cell line. Intracellular $\mathrm{Ca}^{2+}$ release was measured using the fluorescent probe Fura-2 AM. The fluorescence ratio at the two excitation wavelengths (vertical axis) is presented as an indicator of intracellular $\mathrm{Ca}^{2+}$ mobilization. Intracellular $\mathrm{Ca}^{2+}$ concentration was calculated as described in Materials and Methods; bars represent means \pm SEM. SP: substance $\mathrm{P}$, concentration in $\mathrm{nmol} / \mathrm{l}[\mathrm{nM}]$

upon mifepristone stimulation 10 times in U373DPPIV and several hundred times in T98GDPPIV in comparison with the corresponding mifepristone unstimulated transfectants and wild type cells. Upregulation of DPP-IV was also confirmed at the transcriptional level (Table 2). We also determined the expression of transcripts of NK1 receptor and CXCR4, the receptors of SP and SDF-1 $\alpha$, respectively (Table 2).

Thereafter we tested the ability of DPP-IV substrates SP and SDF-1 $\alpha$ to trigger calcium signaling in our model cell lines. SP caused a concentration dependent transient rise of $\left[\mathrm{Ca}^{2+}\right]_{\mathrm{i}}$ in $\mathrm{U} 373$ rendering the cells refractory to repeated stimulation (Fig. 1). This rise of $\left[\mathrm{Ca}^{2+}\right]_{i}$ induced by SP was, however, not significantly affected by upregulation of DPP-IV in U373DPPIV cells (data not shown). To assess the possible effect of prolonged exposure of SP to high DPP-IV activity, U373 cells were exposed to SP preincubated with DPP-IV upregulating T98GDPPIV glioma cells. Such pretreatment of SP abrogated its signaling potential (Fig 2b). SP exposed to DPP-IV upregulating T98GDPPIV cells also lost its capacity to induce the abovementioned resistance of U373 to repeated stimulation by SP not exposed to DPP-IV enzymatic cleavage (Fig. 2). On the contrary, preincubation of SP with T98GDPPIV cells not upregulating DPP-IV did not affect its potential to trigger calcium signaling (Fig. 2a). DPP-IV inhibitors Diprotin A and Lys[Z(NO2)]-pyrrolidide preserved the signaling potential of SP, which confirms that SP was inactivated specifically by DPP-IV enzymatic activity (Fig. 2d-f).

SDF- $1 \alpha$ did not cause measurable changes of $\left[\mathrm{Ca}^{2+}\right]_{\mathrm{i}}$ in any cell line tested (data not shown).

\section{Discussion}

DPP-IV is a widely expressed serine protease that can proteolytically modify a number of biologically active peptides. It is considered to be an important regulator of SP plasma half-life (Ahmad et al. 1992, Wang et al. 1991) and has been shown to affect some SP regulated physiological processes (Grouzmann et al. 2002, Guieu et al. 2006). Functional SP receptors NK1 are widely expressed in astrocytic brain tumors and have been implicated in the regulation of their growth (Palma et al. 2000, Sharif 1998). NK1 receptor triggers a number of signaling cascades including elevation of $\left[\mathrm{Ca}^{2+}\right]_{\mathrm{i}}$ and activation of mitogen-activated protein kinases that can mediate the growth promoting effect of SP (Luo et al. 1996, Palma et al. 1999).

We previously detected DPP-IV enzymatic 
a)

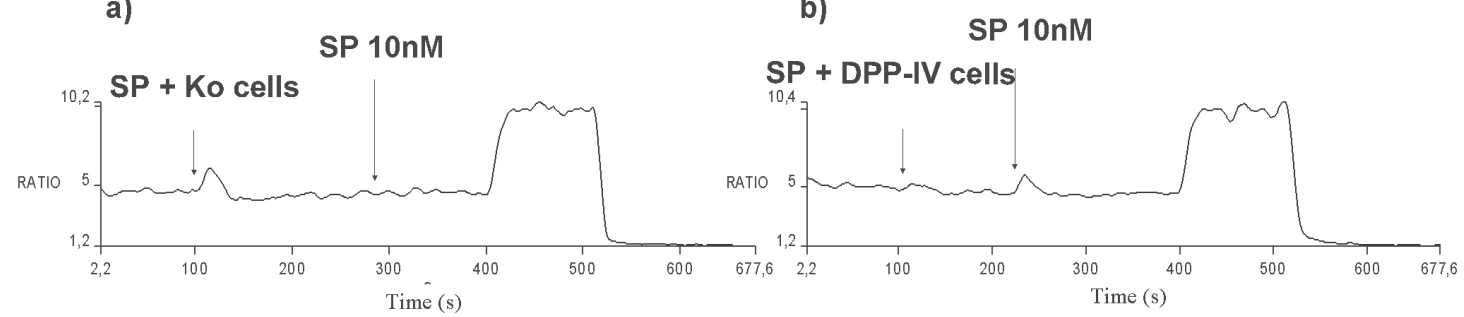

c)

$\mathrm{SP}+\mathrm{Ko}$ cells

d)

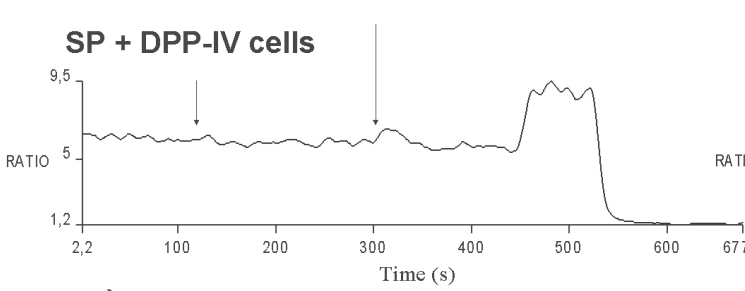

e)

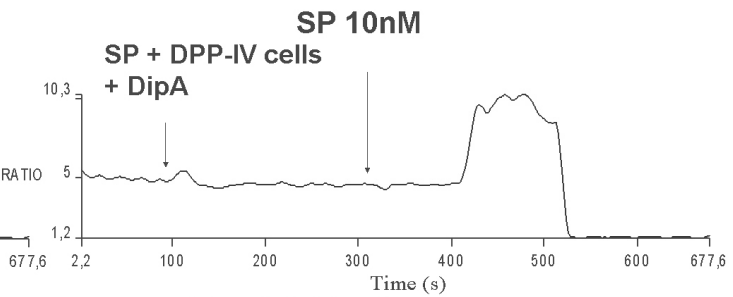

f) $\quad S P+D P P-I V$ cells + DipA

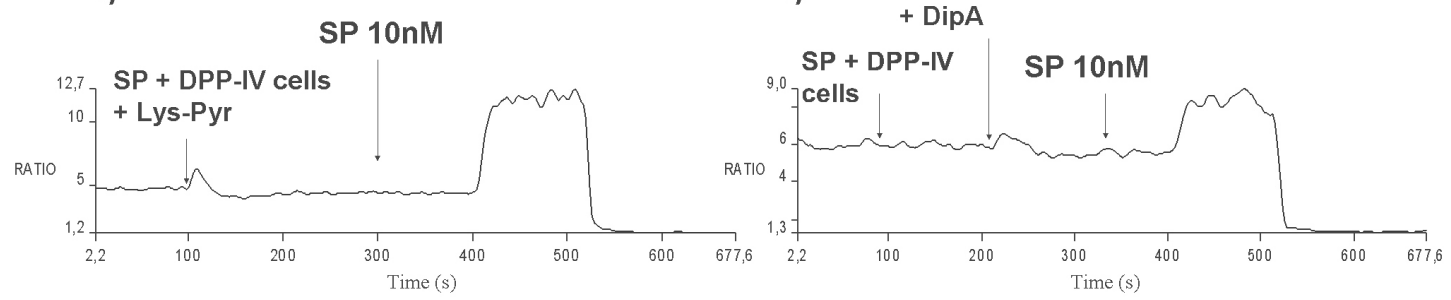

Fig. 2. Substance $P$ loses its ability to trigger calcium signaling in U373 cells after preincubation with DPP-IV overexpressing cells. Intracellular $\mathrm{Ca}^{2+}$ release was monitored as described in Fig.1. Substance $P(\mathrm{SP}, 10 \mathrm{nmol} / \mathrm{l}[\mathrm{nM}])$ was preincubated in the suspension of T98GDPPIV cells that (a) had not been (Ko cells) or (b) had been (DPP-IV cells) induced to overexpress DPP-IV. Plots (d), (e), (f): indicated DPP-IV inhibitors DipA $(200 \mu \mathrm{mol} / \mathrm{l})$ and Lys-Pyr $(200 \mu \mathrm{mol} / \mathrm{l})$ were present in the preincubation mixture. Neither T98GDPPIV cells nor inhibitors alone induced calcium signaling in U373 cell line (data not shown). DipA: Diprotin A; Lys-Pyr: Lys[Z(NO2)]-pyrrolidide.

activity in human astrocytic tumor tissues and glioma cell lines (Šedo et al. 2004, Stremeňová et al. 2006) and observed decreased growth of DPP-IV upregulating transfectants (Bušek et al. 2006). Here we demonstrate that DPP-IV enzymatic activity can influence the signaling potential of SP in glioma cell lines. In agreement with the literature (Sharif 1998, Palma et al. 1999), SP induced $\mathrm{Ca}^{2+}$ signaling in U373 but not in T98G cell line, which well corresponds to the observed substantially lower expression of NK1 receptor mRNA in T98G cells (Table 2). On the contrary, SDF- $1 \alpha$ did not cause measurable changes of $\left[\mathrm{Ca}^{2+}\right]_{i}$ in any cell line tested, although we detected mRNA expression of its receptor CXCR4. However, Oh et al. (2001) also observed SDF- $1 \alpha$ induced changes of $\left[\mathrm{Ca}^{2+}\right]_{\mathrm{i}}$ in glioma cells only after enhancement of CXCR4 expression by cytokines.

Calcium signaling triggered by $\mathrm{SP}$ in U373DPPIV cells upregulating DPP-IV was similar in duration and magnitude to that in wild type U373. This is most likely because the second messenger calcium signaling occurs within seconds while degradation of SP by cell surface DPP-IV into the less active SP5-11 fragment may require longer periods of time. The upregulation of DPP-IV was also much lower in U373DPPIV compared to T98GDPPIV, which did not express NK1 receptors (Table 2). However, it should be considered that i) complex cellular programs such as cell proliferation frequently require prolonged exposure to the particular ligand, and ii) the ligand may be subject to functionally relevant proteolytic cleavage by surrounding cells that neither secrete nor respond to it. To simulate functional interaction of two cell types in SP signaling, U373 cells were exposed to SP that had been preincubated with T98GDPPIV glioma cells overexpressing DPP-IV but lacking NK1 receptor. These experiments demonstrated functional inactivation of SP, which was prevented with specific DPP-IV inhibitors.

Cleavage of SP and other susceptible regulatory molecules may contribute to the growth inhibitory effect of DPP-IV that has been observed in several cell lines (Wesley et al. 1999, 2004, 2005), including glioma cells (Bušek et al. 2006). Our results also suggest that prereceptor modification of signaling peptides by DPP-IV 
enzymatic activity may be physiologically relevant even for DPP-IV negative cells. Thus, DPP-IV present in the tissue microenvironment may represent an important regulator of local humoral signaling.

\section{Conflict of Interest}

There is no conflict of interest.

\section{Acknowledgement}

This work was supported by MSMT 0021620808 and GA UK 16/2005.

\section{References}

AHMAD S, WANG LH, WARD PE: Dipeptidyl(amino)peptidase-IV and aminopeptidase-M metabolize circulating Substance-P in vivo. J Pharmacol Exp Ther 260: 1257-1261, 1992.

BARBERO S, BONAVIA R, BAJETTO A, PORCILE C, PIRANI P, RAVETTI JL, ZONA GL, SPAZIANTE R, FLORIO T, SCHETTINI G: Stromal cell-derived factor 1 alpha stimulates human glioblastoma cell growth through the activation of both extracellular signal-regulated kinases 1/2 and Akt. Cancer Res 63: 1969-1974, 2003.

BUŠEK P, KŘEPELA E, MAREŠ V, VLAŠICOVÁ K, ŠEVČÍK J, ŠEDO A: Expression and function of dipeptidyl peptidase IV and related enzymes in cancer. Adv Exp Med Biol 575: 55-62, 2006.

BUŠEK P, MALÍK R, ŠEDO A: Dipeptidyl peptidase IV activity and/or structure homologues (DASH) and their substrates in cancer. Int J Biochem Cell Biol 36: 408-421, 2004.

De MEESTER I, DURINX C, BAL G, PROOST P, STRUYF S, GOOSSENS F, AUGUSTYNS K, SCHARPE S: Natural substrates of dipeptidyl peptidase IV. Adv Exp Med Biol 477: 67-87, 2000.

DURINX C, LAMBEIR AM, BOSMANS E, FALMAGNE JB, BERGHMANS R, HAEMERS A, SCHARPE S, DE MEESTER I: Molecular characterization of dipeptidyl peptidase activity in serum - soluble CD26/dipeptidyl peptidase IV is responsible for the release of X-Pro dipeptides. Eur J Biochem 267: 5608$5613,2000$.

GROUZMANN E, MONOD M, LANDIS B, WILK S, BRAKCH N, NICOUCAR K, GIGER R, MALIS D, SZALAYQUINODOZ I, CAVADAS C, MOREL DR, LACROIX JS: Loss of dipeptidylpeptidase IV activity in chronic rhinosinusitis contributes to the neurogenic inflammation induced by substance $\mathrm{P}$ in the nasal mucosa. FASEB J 16: 1132-1134, 2002.

GUIEU R, FENOUILLET E, DEVAUX C, FAJLOUN Z, CARREGA L, SABATIER JM, SAUZE N, MARGUET D: CD26 modulates nociception in mice via its dipeptidyl-peptidase IV activity. Behav Brain Res 166: 230-235, 2006.

LAMBEIR AM, DURINX C, SCHARPE S, DE MEESTER I: Dipeptidyl-peptidase IV from bench to bedside: An update on structural properties, functions, and clinical aspects of the enzyme DPP IV. Crit Rev Clin Lab Sci 40: 209-294, 2003.

LIVAK KJ, SCHMITTGEN TD: Analysis of relative gene expression data using real-time quantitative PCR and the 2 (Delta Delta C(T)) method. Methods 25: 402-408, 2001.

LUO WH, SHARIF TR, SHARIF M: Substance P-induced mitogenesis in human astrocytoma cells correlates with activation of the mitogen-activated protein kinase signaling pathway. Cancer Res 56: 4983-4991, 1996.

MASUR K, SCHWARTZ F, ENTSCHLADEN F, NIGGEMANN B, ZAENKER KS: DPPIV inhibitors extend GLP-2 mediated tumour promoting effects on intestinal cancer cells. Regul Pept 137: 147-155, 2006.

MENTLEIN R: Dipeptidyl-peptidase IV (CD26)-role in the inactivation of regulatory peptides. Regul Pept 85: 9-24, 1999.

OH JW, DRABIK K, KUTSCH O, CHOI C, TOUSSON A, BENVENISTE EN: CXC chemokine receptor 4 expression and function in human astroglioma cells. J Immunol 166: 2695-704, 2001.

PALMA C, BIGIONI M, IRRISSUTO C, NARDELLI F, MAGGI CA, MANZINI S: Anti-tumour activity of tachykinin NK1 receptor antagonists on human glioma U373 MG xenograft. Br J Cancer 82: 480-487, 2000.

PALMA C, MAGGI CA: The role of tachykinins via NK1 receptors in progression of human gliomas. Life Sci 67: 985$1001,2000$. 
PALMA C, NARDELLI F, MANZINI S, MAGGI CA: Substance P activates responses correlated with tumour growth in human glioma cell lines bearing tachykinin NK1 receptors. Br J Cancer 79: 236-243, 1999.

RUBIN JB, KUNG AL, KLEIN RS, CHAN JA, SUN YP, SCHMIDT K, KIERAN MW, LUSTER AD, SEGAL RA: A small-molecule antagonist of CXCR4 inhibits intracranial growth of primary brain tumors. Proc Natl Acad Sci USA 100: 13513-13518, 2003.

ŠEDO A, BUŠEK P, SCHOLZOVÁ E, MALÍK R, VLAŠICOVÁ K, JANÁČKOVÁ S, MAREŠ V: 'Dipeptidyl peptidase-IV activity and/or structure homologs' (DASH) in growth-modulated glioma cell lines. Biol Chem 385: 557-559, 2004.

ŠEDO A, Ǩ̌EPELA E, KASAFÍREK E: A kinetic fluorometric assay of dipeptidyl peptidase-IV in viable humanblood mononuclear-cells. Biochimie 71: 757-761, 1989.

SHARIF M: Mitogenic signaling by substance P and bombesin-like neuropeptide receptors in astrocytic/glial brain tumor-derived cell lines. Int J Oncol 12: 273-286, 1998.

STREMEŇOVÁ J, MAREŠ V, DBALÝ V, MAREK J, SYRŮČEK M, KŘEPELA E, VANÍČKOVÁ Z, VLASICOVÁ K, ŠEDO A: Regulation of dipeptidyl peptidase-IV activity and/or structure homologues (DASH) in human brain tumors: an association with WHO grade? Physiol Res 55: 43P, 2006.

SULDA ML, ABBOTT CA, HILDEBRANDT M: DPIV/CD26 and FAP in cancer: A tale of contradictions. Adv Exp Med Biol 575: 197-206, 2006.

UBL JJ, VOHRINGER C, REISER G: Co-existence of two types of $\left[\mathrm{Ca}^{2+}\right]_{\mathrm{i}}$-inducing protease-activated receptors (PAR-1 and PAR-2) in rat astrocytes and C6 glioma cells. Neuroscience 86: 597-609, 1998.

WANG LH, AHMAD S, BENTER IF, CHOW A, MIZUTANI S, WARD PE: Differential processing of substance-P and neurokinin-A by plasma dipeptidyl(amino)peptidase-IV, aminopeptidase-M and angiotensin converting enzyme. Peptides 12: 1357-1364, 1991.

WESLEY UV, ALBINO AP, TIWARI S, HOUGHTON AN: A role for dipeptidyl peptidase IV in suppressing the malignant phenotype of melanocytic cells. $J$ Exp Med 190: 311-322, 1999.

WESLEY UV, MCGROARTY A, HOMOYOUNI A: Dipeptidyl peptidase inhibits malignant phenotype of prostate cancer cells by blocking basic fibroblast growth factor signaling pathway. Cancer Res 65: 1325-1334, 2005.

WESLEY UV, TIWARI S, HOUGHTON AN: Role for dipeptidyl peptidase IV in tumor suppression of human non small cell lung carcinoma cells. Int J Cancer 109: 855-866, 2004. 